\title{
ANALISIS PELUANG DAN TANTANGAN LEMBAGA KEUANGAN SYARIAH UNTUK MENINGKATKAN DAYA SAING MENGHADAPI MASYARAKAT EKONOMI ASEAN
}

\author{
Yayat Rahmat Hidayat \\ Universitas Islam Bandung Jl. Ranggagding No. 8 Bandung \\ :yayatrahmathidayat@unisba.ac.id
}

\begin{abstract}
Abstrak
Indonesia memiliki potensi yang sangat besar untuk mengembangkan lembaga keuangan syariah. Indonesia memiliki populasi muslim yang besar dan sumber daya alam yang melimpah yang dapat dijadikan sebagai underlying transaction. Akan tetapi banyak kendala yang dihadapi Indonesia untuk mengembangkan lembaga keuangan syariah sehingga memiliki daya saing yang rendah dibandingkan dengan lembaga keuangan konvensional dan lembaga keuangan syariah dari negara ASEAN yang lain. Penelitian ini mengunakan metode penelitian kualitatif dengan teknik analisis deskriptif. Hasil penelitian ini menunjukkan bahwa kendala yang dihadapi Indonesia adalah kurangnya sumber daya manusia ekonomi syariah baik dalam kuantitas dan kualitas, kurangnya pengetahuan dan kesadaran dalam ekonomi syariah, kurangnya inovasi dan diferensiasi produk, dan kurangnya dukungan pemerintah baik regulasi atau penerbitan modal. Upaya dan strategi diperlukan untuk meningkatkan daya saing ekonomi syariah di ASEAN Economic Community (AEC) adalah peningkatan sumber daya manusia baik dalam kualitas dan kuantitas, sosialisasi dan pendidikan di masyarakat, peningkatan layanan dan diferensiasi produk, dan dukungan dari semua pemangku kepentingan.
\end{abstract}

Kata kunci: Ekonomi Syariah, Masyarakat Ekonomi ASEAN (MEA)

\begin{abstract}
Indonesia has a big potential in the development sharia financial institution, it has a large number of Muslim population and abundant natural resources that can be used as an underlying transaction. But lots of obstacles has been faced by Indonesia while developing its sharia financial institution so that they have low competitiveness compared with conventional financial institutions and sharia financial institutions from other ASEAN. This research uses qualitative method with descriptive analysis technique. The results of this study indicate that the constraints faced by Indonesia are the lack of human resources of sharia economy both in quantity and quality, lack of knowledge and awareness in sharia economy, lack of innovation and product differentiation, and lack of government support either regulation or capital issuance. Efforts and strategies needed to improve the competitiveness of sharia economy in the ASEAN Economic Community (AEC) are the improvement of human resources both in quality and quantity, socialization and education in the community, service improvement and product differentiation, and support from all stakeholders.
\end{abstract}

Keyword: Sharia Economy, ASEAN Economic Community (AEC)

\section{PENDAHULUAN}

\section{A. Latar Belakang Masalah}

Indonesia merupakan Negara dengan jumlah penduduk muslim terbanyak di dunia. Berdasarkan sensus penduduk
Indonesia tahun 2010, jumlah penduduk muslim Indonesia sebanyak 207176162 jiwa. Dengan demikian Indonesia berpeluang untuk menjadi Negara dengan perkembangan dan nilai aset Ekonomi Syariah tertinggi di dunia. Impian untuk 
menjadi Global Player seharusnya bisa terwujud dikarenakan selain memiliki jumlah penduduk muslim terbesar di dunia, Indonesia juga memiliki kekayaan alam yang melimpah yang dapat dijadikan sebagai underlying transaksi industri keuangan syariah (BPS, 2010).

Nilai aset perbankan syariah masih jauh di bawah nilai aset perbankan konvensional. Data Statistik Perbankan Indonesia mencatat, sampai Desember 2017 total aset berdasarkan kegiatan usaha bank umum syariah sebanyak Rp. 287,55 triliun masih jauh di bawah bank umum konvensional yang mencapai Rp. 7.099,60 triliun. Maka total aset berdasarkan kegiatan usaha bank umum syariah hanya berada pada kisaran 3,89\% sedangkan bank umum konvensional 96,11\% (OJK, 2018). Begitu pula dengan asuransi syariah. Nilai aset asuransi syariah pada tahun 2017 sebesar Rp. 40,52 triliun dari total asset asuransi sebesar Rp. 628,68 triliun. Nilai aset asuransi syariah hanya $6,45 \%$ dan asuransi konvensional mencapai 93,54\%. Sedangkan pada pasar modal dan keuangan, Nenny Kurnia dkk dalam Islamic Finance Outlok 2015 mencatat nilai sukuk korporasi pada agustus 2014 sebesar Rp. 6,8 triliun atau sebesar 3\% dan obligasi korporasi konvensional mencapai 211,7 triliun atau sebesar 97\%. Sedangkan nilai aset sukuk Negara mencapai $31 \%$ dan obligasi Negara konvensional mencapai 69\% dari total $\mathrm{Rp}$. 412,82 triliun (Kurnia, 2015).

Dari perbandingan aset saja kita bisa menyimpulkan bahwa lembaga keuangan syariah masih memiliki skala ekonomi yang kecil dibandingkan dengan lembaga keuangan konvensional. Dengan demikian dapat dikatakan bahwa lembaga keuangan syariah memiliki tingkat efisiensi dan daya saing yang rendah dibandingkan dengan bank konvensional yang ada di Indonesia. Apalagi dalam Masyarakat Ekonomi ASEAN (MEA), lembaga keuangan syariah Indonesia akan bersaing bukan hanya dengan bank konvensional Indonesia saja, tetapi juga dengan lembaga keuangan konvensional dan lembaga keuangan syariah dari seluruh Negara-negara ASEAN. Tentunya hal ini bukanlah hal yang mudah untuk dihadapi. Akan tetapi hal ini juga bukanlah sesuatu yang tidak mungkin dapat diatasi. Kerjasama dari semua pihak sangatlah dibutuhkan, mulai dari praktisi, akademisi, pemerintah, dan para ulama dalam meningkatkan kinerja dan pangsa pasar lembaga keuangan syariah. Dengan demikian akan tercapai skala ekonomi yang besar sehingga lembaga keuangan syariah akan lebih efisien dalam kegiatan usahanya sehingga memiliki daya saing yang tinggi dengan bank konvensional dan bank syariah dari Negara-negara ASEAN yang lain. 
Yayat Rahmat $\mathrm{H}$, Analisis Peluang dan Tantangan Lembaga Keuangan Syari'ah...

\section{B. Tujuan dan Manfaat Penelitian}

Tujuan yang ingin dicapai adalah untuk menjelaskan peluang dan tantangan lembaga keuangan syariah dalam menghadapi Masyarakat Ekonomi ASEAN (MEA) dan strategi lembaga keuangan syariah untuk memenangkan persaingan Masyarakat Ekonomi ASEAN (MEA). Adapun manfaat yang ingin dicapai adalah (1) Secara teoritis, memperkaya khazanah keilmuan ekonomi syariah memperkaya referensi tentang kajian ekonomi syariah dalam menghadapi Masyarakat Ekonomi ASEAN (MEA) dan (2) Secara praktis, agar bisa diambil manfaatnya baik oleh praktisi ekonomi syariah dan pemerintah agar bisa meningkatkan daya saing ekonomi syariah di ASEAN.

\section{Metode Penelitian}

Metode penelitian yang digunakan adalah metode kualitatif dengan pendekatan deskriptif analisis. Sumber data diperoleh dari sumber sekunder baik berupa buku, jurnal, publikasi ilmiah, dan sumber lain yang relevan.

\section{PEMBAHASAN}

\section{A. Landasan Teori}

\section{Ekonomi Syariah}

a. Pondasi ekonomi syariah
Dalam mengambil setiap keputusan, manusia selalu berfikir secara ekonomi. Pilihan mana yang paling menguntungkan dan akan mendatangkan kemaslahatan yang lebih baik. Manusia selalu berfikir secara ekonomi dan selalu mempertimbangkan untung/kemaslahatan dan rugi/kemadharatan dalam setiap tindakan yang diambilnya. Oleh karena itu ilmu ekonomi adalah ilmu untuk memilih. Memilih upaya yang paling menguntungkan untuk memenuhi kebutuhan. Memilih barang dan jasa yang paling dibutuhkan untuk memperoleh kemaslahatan dengan keterbatasan sumber daya yang dimiliki. Jadi yang terbatas itu bukanlah alat pemuas kebutuhan, akan tetapi sumber daya yang dimiliki untuk memperoleh alat pemuas kebutuhan. Karena semua yang ada di bumi ini diciptakan untuk manusia dan masih banyak sumber daya yang belum bisa dimanfaatkan dan digarap oleh manusia.

Distribusi kekayaan yang tidak merata menyebabkan kesenjangan antara orang miskin dan orang kaya semakin jauh. Hal ini dapat dilihat dari rasio gini Indonesia yang mencapai 0,4 pada september 2017. Masalah distribusi sumber daya yang tidak merata ini merupakan salah satu masalah utama dalam ekonomi syariah agar harta tidak menumpuk dan berputar di kalangan orang-orang kaya saja (QS 59:7). Oleh karena itu, dalam ekonomi syariah terdapat beberapa solusi untuk mendistribusikan sumber daya 
tersebut supaya merata diantaranya dengan pengelolaan ZIS (zakat, infaq, dan shadaqah). Potensi ZIS Indonesia sangatlah besar apabila bisa dikelola dengan baik. Tentunya dana tersebut dapat dialokasikan kepada orangorang miskin sebagai bantuan modal baik untuk memulai usaha atau untuk memperbesar skala ekonominya.

Pada dasarnya masalah ekonomi merupakan ranah muamalah. Muamalah sendiri memiliki hukum asal al-ibahah (boleh) kecuali yang dilarang. Artinya tindakan atau aktivitas apapun dalam ranah ekonomi adalah boleh kecuali jika ada dalil yang melarangnya. Oleh karena itu, dalam praktiknya ekonomi syariah seringkali memiliki kesamaan dengan ekonomi konvensional. Tetapi ini bukan berarti ekonomi syariah sama dengan ekonomi konvensional. Terdapat perbedaan mendasar antara ekonomi syariah dan ekonomi konvensional, yaitu perbedaan ideologinya. Sehingga, meskipun ada beberapa hal yang kelihatan sama, tetapi dasar dalam menentukan dan melakukan hal tersebut jelas berbeda. Ekonomi syariah memiliki ideologi Islam. Segala sesuatunya didasarkan pada AlQur'an dan as-Sunnah Adiwarman Karim (Karim, 2013) menyatakan bahwa ekonomi syariah dibangun di atas prinsip-prinsip religious yang berorientasi bukan hanya untuk kehidupan dunia semata, tapi juga berorientasi pada kehidupan akhirat.
Sedangkan ekonomi konvensional bersifat liberal yang didasarkan pada akal semata. Sehingga ekonomi konvensional bersifat positivistic. Agama, Tuhan, nilai, dan norma secara drastis dikeluarkan dari struktur pemikiran ekonomi konvensional. Ekonomi konvensional hanya berorientasi pada kehidupan dunia semata dan menafikan tanggung jawab manusia kepada Tuhan di akhirat.

Adiwarman Karim (Karim, 2013) mengatakan bahwa ekonomi syariah didasarkan pada lima nilai universal, yaitu Tauhid (keimanan), 'Adl (keadilan), Nubuwwah (kenabian), Khilafah (Pemerintahan), dan Ma'ad (hasil). Kelima dasar inilah yang menjadi pondasi utama dalam mengembangkan teori ekonomi syariah. Tauhid merupakan suatu kepercayaan bahwa tidak ada Tuhan selain Allah. Dialah yang telah menciptakan manusia dan seluruh alam ini. Dialah pemilik hakiki segala yang ada di langit dan di bumi. Manusia hanyalah sebagai khalifah di muka bumi yang diamanatkan untuk menjaga, memelihara, dan memanfaatkannya. Sehingga dalam melakukan segala sesuatu, tidak terkecuali dalam ranah ekonomi, manusia harus senantiasa mengikuti aturanaturan yang telah digariskan oleh Allah.

Prinsip dasar ekonomi syariah yang kedua yaitu keadilan. Manusia diperintahkan agar selalu bertindak adil (QS. 49: 9) , 
termasuk dalam ekonomi. Manusia sebagai khalifah di muka bumi harus senantiasa menjaga hukum Allah dan menjamin pemakaian segala sumber daya diarahkan untuk kesejahteraan manusia (Karim, 2013). Hal ini untuk meredam keserakahan manusia yang selalu ingin mencari keuntungan pribadi tanpa memikirkan orang lain dan kerusakan alam. Prinsip yang ketiga adalah kenabian. Maksudnya adalah para pelaku ekonomi harus senantiasa mengikuti apa yang telah diajarkan dan dicontohkan oleh Nabi Muhammad SAW, tidak terkecuali dalam kegiatan ekonomi. Sikap jujur, amanah, tabligh, dan fatanah harus selalu tercermin pada setiap perilaku ekonomi seorang muslim. Seorang muslim dilarang untuk berlaku curang dalam ekonomi. Bahkan, perbuatan curang tersebut akan mendapatkan adzab dan balasan yang setimpal di akhirat kelak (QS. 83: 1).

\section{Prinsip yang keempat adalah} khilafah. Manusia adalah sebagai khalifah di muka bumi (QS. 2: 30). Setiap manusia adalah pemimpin dan akan dimintai pertanggung jawaban atas apa yang dipimpinnya, baik sebagai individu, kepala keluarga, pemimpin masyarakat, maupun kepala Negara. Nilai ini mendasari prinsip kehidupan manusia dalam Islam. Fungsi utamanya menurut Adiwarman Karim (Karim, 2013) adalah agar tercipta keteraturan interaksi antar kelompok, termasuk dalam bidang ekonomi. Prinsip yang kelima adalah ma'ad. Segala yang manusia upayakan di dunia ini pada intinya adalah untuk mencari bekal untuk kehidupan yang kekal di akhirat. Dengan berpegang pada prinsip ini maka manusia akan selalu menjaga perbuatannya untuk berbuat baik dan menghindari dari perbuatan fasad, fahsya, dan munkar. Dengan demikian akan tercipta kehidupan yang adil dan harmonis di dunia ini, begitupun dalam aktivitas ekonomi.

b. Pengertian ekonomi syariah

Ekonomi syariah merupakan ilmu yang mempelajari perilaku muslim yang beriman dalam suatu masyarakat Islam dengan mengikuti Al-Qur'an, Hadits, Ijma', dan Qiyas. Segala aturan yang Allah turunkan dalam sistem Islam bertujuan untuk mencapai kebaikan dan kesejahteraan serta menghapuskan kejahatan, kesengsaraan, dan kerugian manusia. Begitupun dalam bidang ekonomi yang bertujuan membantu manusia memperoleh kemenangan di dunia dan di akhirat (Hosen, 2007). Ekonomi Islam didasarkan pada paradigma yang memiliki keadilan sosial-ekonomi sebagai tujuan utamanya. Tujuan ini bersumber pada keyakinan bahwa manusia adalah khalifah di muka bumi. Mereka adalah saudara bagi satu sama lain dan semua sumber daya yang mereka miliki merupakan titipan dari Allah untuk mencapai kesejahteraan semua 
manusia. Manusia akan diminta pertanggung jawaban tentang bagaimana cara mendapatkan dan menggunakan hartanya di akhirat kelak (Chapra, 2002).

Al-Assal dan Ahmad Abdul Karim (Nawawi, 2009) mengatakan bahwa ekonomi syariah merupakan sekumpulan dasar-dasar secara umum ekonomi yang disimpulkan dari Al-Qur'an dan As-Sunnah dan merupakan bangunan perekonomian yang didirikan atas landasan dasar-dasar tersebut sesuai dengan lingkungan dan masanya. Jadi, inti dari ekonomi syariah mencakup dua hal pokok yang tetap dan yang tidak tetap. Hal pokok yang tetap yaitu dasar umum dan nilai-nilai ekonomi syariah diambil dari Al-Qur'an dan AsSunnah. Sedangkan hal yang tidak tetap yaitu masalah ekonomi disesuaikan dengan tuntutan lingkungan dan masanya sesuai dengan prinsip-prinsip Islam. Abdulrahman Yousri Ahmed (Ahmed, 2002) menyatakan bahwa ekonomi syariah adalah ilmu pengetahuan yang mempelajari kemungkinan terbaik untuk menggunakan sumber daya ekonomi yang tersedia, yang telah diberikan Allah, untuk memaksimalkan produksi serta menghasilkan barang dan jasa yang halal yang dibutuhkan manusia saat ini dan saat yang akan datang, serta mendistribusikannya dalam kerangka syariah.
Dari beberapa pengertian di atas dapat dikatakan bahwa ekonomi syariah merupakan cabang ilmu pengetahuan yang mempelajari usaha dalam mewujudkan kesejahteraan manusia melalui alokasi dan distribusi sumber daya sesuai dengan kerangka dan maqasid as-syariah.

c. Ciri-ciri ekonomi syariah

Ekonomi syariah tidak mengekang individu secara berlebihan sehingga mengakui adanya kepemilikan individu dan kepemilikan publik. Hal ini bertolak belakang dengan ekonomi konvensional yang hanya mengakui kepemilikian individu saja atau kepemilikan publik saja. Dalam ekonomi syariah berlaku sistem multiple ownership. Dengan demikian akan tercipta keseimbangan dalam perekonomian.

Ciri yang kedua adalah adanya freedom to act atau kebebasan untuk bertindak. Setiap muslim dibebaskan untuk berusaha dalam memenuhi kebutuhan hidupnya. Islam tidak mengekang umatnya untuk berusaha dalam menjalankan kehidupan ekonominya, sepanjang tidak melanggar aturan. Hal-hal yang dilarang seperti riba, tadlis, maysir, dan ihtikar haruslah dijauhi oleh setiap muslim. Sepanjang tidak melanggar hal-hal yang diharamkan maka setiap muslim diberi kebebasan untuk melakukan usaha dan transaksi 
Yayat Rahmat $\mathrm{H}$, Analisis Peluang dan Tantangan Lembaga Keuangan Syari'ah...

apapun. Hal ini dikarenakan hukum asal dari muamalah adalah dibolehkan, kecuali yang ada larangannya.

Ciri yang ketiga yaitu adanya jaminan sosial. Islam mengatur agar keadilan social ini dapat terwujud. Misalkan saja untuk meminimalisir kesenjangan social maka Islam memerintahkan tentang agar orang yang kaya mengeluarkan zakat dari sebagian harta yang dimiliki. Pemerintah sebagai ulil amri bertanggung jawab untuk menjamin terciptanya keadilan sosial di masyarakat. Setiap sistem ekonomi memiliki tujuan yang sama yaitu untuk menciptakan sistem ekonomi yang adil. Akan tetapi tidak semua sistem ekonomi mampu menciptakan sistem ekonomi yang adil (Karim, 2013).

\section{Perekonomian bebas bunga/riba}

Perbedaan mendasar ekonomi syariah dengan ekonomi konvensional, terutama pada lembaga keuangan syariah, menggunakan sistem bebas bunga/riba. Secara etimologi, riba berarti tambahan. Syaikh Muhammad Abduh berpendapat bahwa riba yaitu penambahanpenambahan yang disyaratkan oleh orang yang memiliki harta pada orang yang meminjam hartanya, karena pengunduran janji pembayaran oleh peminjam dari waktu yang telah ditentukan (Suhendi, 2011). Muhammad ibnu Abdullah ibnu Al-
Arabi Al-Maliki menyatakan bahwa tambahan yang termasuk riba adalah tambahan yang diambil tanpa ada suatu iwad (pengganti/penyeimbang) yang dibenarkan syariah (Sudarsono, 2012). Menurut Sayyid Sabiq dalam Kitab Fiqih Sunah, yang dimaksud riba adalah tambahan atas modal, baik sedikit ataupun banyak (Sudarsono, 2012). M. Nejatullah Shidqi (Shidqi, 2004) menyatakan bahwa riba adalah suatu tambahan yang dibebankan pada peminjam dalam jangka waktu tertentu. Dengan demikian dapat dikatakan bahwa riba adalah suatu tambahan atas pinjaman/modal yang disyaratkan pada peminjam dalam jangka waktu yang sudah ditentukan.

Riba merupakan sesuatu yang diharamkan (QS. 2: 275). Manusia dilarang untuk mengambil, memakan, dan memanfaatkan harta riba (QS. 4: 161) dan Allah akan menghapus berkah dari harta riba (QS. 2: 276). Riba merupakan suatu perbuatan yang dapat menyebabkan putusnya perbuatan baik terhadap sesame manusia dengan cara utang-piutang. Karena riba menghendaki pengambilan harta orang lain dengan tidak ada imbangannya (Suhendi, 2011). Riba dapat memperbesar kessenjangan sosial antara orang miskin dan orang kaya, karena riba dalam praktiknya adalah pemerasan orang miskin oleh orang kaya. 
Secara umum, riba terbagi menjadi empat, yaitu riba qardh, riba jahiliyah, riba fadhl, dan riba nasiah. Riba qardh adalah suatu manfaat atau tingkat kelebihan tertentu yang disyaratkan pada orang yang berutang. Riba jahiliyah adalah beban utang yang harus dibayar lebih dari pokoknya karena orang yang berutang tidak mampu membayar pada waktu yang telah ditetapkan. Riba fadhl adalah pertukaran antara barang sejenis yang tidak sama, baik kualitas, kuntitas, atau waktu penyerahannya (Sudarsono, 2012). Sedangkan riba nasiah adalah riba yang pembayarannya atau penukarannya berlipat ganda karena waktunya diundurkan (Suhendi, 2011).

Riba merupakan suatu perbuatan yang sangat merugikan dan membawa banyak kemadharatan. Selain itu, riba juga diharamkan dalam Islam. Ekonomi syariah merupakan ekonomi yang bebas dari riba. Riba digantikan dengan akad bagi hasil dan akad-akad yang dibolehkan secara syar'i lainnya. Riba merupakan suatu sistem yang lebih mengoptimalkan pemenuhan kepentingan pribadi sehingga kurang mempertimbangkan dampak sosial yang ditimbulkannya. Sedangkan bagi hasil lebih berorientasi pada pemenuhan kemaslahatan hidup manusia (Sudarsono, 2012). Dengan demikian, ekonomi syariah juga dikenal dengan suatu sistem yang berdasarkan bagi hasil.

Ekonomi syariah menghendaki transaksi-transaksi yang bebas dari riba, gharar, dan maysir. Transaksi keuangan dalam Islam didasarkan pada akad-akad yang diperbolehkan secara syar'i, seperti akad jual beli, akad bagi hasil, akad sewa menyewa, akad titipan, dan sebagainya. Akad-akad dalam ekonomi syariah bukan hanya akan mendatangkan keberkahan dan keuntungan duniawi berupa materi, tetapi juga akan menyelamatkan umat dari api neraka.

\section{Lembaga Keuangan Syariah}

Lembaga keuangan Syariah merupakan Lembaga keuangan yang dalam operasional usahanya berdasarkan prinsip Syariah. Lembaga keuangan Syariah secara umum dapat dibedakan menjadi Lembaga keuangan bank dan non bank. Lembaga keuangan Syariah mulai berkembang di Indonesia tahun 1992 dengan berdirinya Bank Muamalat sebagai bank Syariah pertama di Indonesia. Saat ini di Indonesia terdapat 13 BUS, 34 UUS, dan 167 BPR. Bank Syariah adalah Lembaga keuangan yang usaha pokoknya memberikan kredit dan jasa-jasa lain dalam lalu lintas pembayaran dan peredaran uang yang dalam operasionalnya didasarkan prinsip-prinsip Syariah (Sudarsono, 2012). 
Yayat Rahmat $\mathrm{H}$, Analisis Peluang dan Tantangan Lembaga Keuangan Syari'ah...

Lembaga keuangan non bank adalah lembaga keuangan yang memberikan jasajasa keuangan dan menarik dana dari masyarakat secara tidak langsung (non depository). Lembaga keuangan non bank terdiri dari asuransi, dana pensiun, pegadaian, pasar modal, sukuk, dan sebagainya. Asuransi merupakan perjanjian antara dua belah pihak atau lebih, dimana pihak penanggung mengikat diri pada pihak tertanggung, dengan memperoleh premi asuransi untuk memberikan penggantian pada tertanggung atas risiko yang ditanggungkan (UU No.2 Tahun 1992). Dana Pensiun merupakan perusahaan yang kegiatannya mengelola dana pension suatu perusahaan pemberi kerja. Pengadaian merupakan lembaga keuangan yang menyediakan fasilitas pinjaman dengan jaminan tertentu. Pasar Modal merupakan pasar tempat pertemuan dan melakukan transaksi antara pencari dana dengan para penanam modal, dengan instrumen utama saham dan obligasi. Sedangkan sukuk merupakan obligasi (surat utang) dengan prinsip Syariah.

\section{Masyarakat Ekonomi ASEAN}

(MEA)

Negara-negara ASEAN telah menyepakati ASEAN Free Trade Area (AFTA) pada pertemuan kepala negara ASEAN pada tahun 1992 dengan persiapan selama 15 tahun. Kemudian perjanjian ini direvisi pada tahun 2007 dengan masuknya Cina pada tahun 2012 menjadi ASEAN-China Free Trade Area (ACFTA) dan diberlakukannya Masyarakat Ekonomi ASEAN (MEA) pada tahun 2015. Dengan demikian MEA merupakan kelanjutan dari kebijakan sebelumnya, yaitu AFTA. Perbedaannya yaitu AFTA lebih menekankan pada pengurangan dan penghapusan hambatan tarif, sedangkan MEA lebih menekankan pada pengurangan dan penghapusan hambatan non-tarif.

\section{Masyarakat Ekonomi ASEAN} (MEA) adalah sebuah integrasi ekonomi ASEAN dalam menghadapi perdagangan bebas antar Negara-negara ASEAN. Seluruh Negara anggota ASEAN telah menyepakati perjanjian ini. MEA dirancang untuk mewujudkan wawasan ASEAN 2020. Dengan demikian maka perdagangan barang dan jasa dapat dilakukan secara bebas tanpa hambatan, baik tarif maupun non tarif. Hal ini bertujuan untuk menjadikan kawasan ASEAN menjadi kawasan ekonomi yang kompetitif serta mempercepat pembangunan, pemerataan kesejahteraa, dan mengurangi kesenjangan sosialekonomi. Selain itu, pelaksanaan MEA juga diharapkan dapat menarik lebih banyak Foreign Direct Investment (FDI) 
serta meningkatkan perdagangan antar negara-negara ASEAN.

Humprey Wangke (Wangke, 2014) mengatakan bahwa penerapan MEA mengacu pada ASEAN Economic Community (AEC) Blueprint. AEC Blueprint memuat empat pilar utama, yaitu: (1) ASEAN sebagai pasar tunggal dan berbasis produksi tunggal yang didukung dengan elemen aliran bebas barang, jasa, investasi, tenaga kerja terdidik, dan aliran modal yang lebih bebas; (2) ASEAN sebagai kawasan dengan daya saing ekonomi tinggi, dengan elemen peraturan kompetisi, perlindungan konsumen, hak atas kekayaan intelektual, pengembangan infrastuktur, dan perpajakan; (3) ASEAN sebagai kawasan dengan pengembangan ekonomi yang merata dengan pengembangan ekonomi kecil dan menengah, dan prakarsa integrasi ASEAN untuk Negara-negara Kamboja, Myanmar, Laos, dan Vietnam; dan (4) ASEAN sebagai kawasan yang terintegrasi secara penuh dengan perekonomian global dengan elemen pendekatan yang koheren dalam hubungan ekonomi di luar kawasan, dan meningkatkan peran serta dalam jejaring produksi global.

Pelaksanaan MEA berdampak pada penurunan dan penghapusan biaya tarif ekspor-impor dan pengurangan dan penghapusan hambatan non tarif.
Perdagangan bebas di kawasan ASEAN akan terbuka, dan diharapkan mampu mendorong perekonomian negara-negara anggota. Keuntungan yang diperoleh dengan diberlakukannya MEA adalah: (1) Meningkatkan pendapatan negara melalui perdagangan ekspor-impor; (2) Membuka indrustrialisasi di kawasan negara-negara ASEAN; (3) Memperluas lapangan kerja professional dan memberikan kesempatan berkarir di kawasan negara-negara ASEAN.

Dengan adanya MEA diharapkan akan mendorong produktivitas dan memperkuat integrasi regional pada sektor-sektor ekonomi dan terciptanya kebebasan pelaku-pelaku usaha dan tenaga kerja terdidik untuk bekerja di negaranegara anggota ASEAN. Biaya transaksi akan mengalami penurunan karena adanya pengurangan dan penghapusan pajak ekspor-impor, yang pada akahirnya akan meningkatkan pendapatan. Pada akhirnya, penerapan MEA akan menjadikan ASEAN sebagai pasar tunggal yang berbasis produksi. Pasar tunggal dan basis produksi ASEAN berarti liberalisasi pada arus barang, jasa, investasi, modal, dan tenaga kerja.

\section{B. Hasil Penelitian}

1. Peluang dan Tantangan Lembaga

Keuangan Syariah Menghadapi

MEA 
Yayat Rahmat $\mathrm{H}$, Analisis Peluang dan Tantangan Lembaga Keuangan Syari'ah...

Ekonomi syariah merupakan suatu sistem dalam Islam dalam mengatur urusan ekonomi berdasarkan aturan AlQur'an dan As-Sunah. Ekonomi Syariah meliputi semua kegiatan ekonomi yang berlandaskan aturan-aturan Islam. Perkembangan ekonomi Syariah di Indonesia ditandai dengan munculnya berbagai Lembaga Keuangan Syariah baik bank ataupun non bank, perusahaan Syariah, hotel Syariah, pasar modal dan pasar uang Syariah, sampai pariwisata Syariah. Menjamurya perusahaan dan Lembaga keuangan Syariah tersebut menimbulkan persaingan satu sama lain. Terlebih sekarang persaingan tersebut bukan hanya dengan lembaga keuangan dalam negeri saja, mengingat Indonesia saat ini telah memasuki Masyarakat Ekonomi ASEAN (MEA).

Pertumbuhan ekonomi Indonesia selama tiga tahun terakhir mengalami tren kenaikan yaitu sebesar $4,79 \%$ pada tahun $2015,5,02 \%$ pada tahun 2016 , dan $5,07 \%$ pada tahun 2017 (OJK, 2017). Tren yang positif ini diharapkan akan terus berlanjut dan menjadi modal utama dalam menghadapi persaingan di era Masyarakat Ekonomi Asean.

Industri keuangan syariah di
Indonesia diproyeksikan akan terus
mengalami peningkatan mengingat
mayoritas penduduk Indonesia adalah

bergama Islam. Ini merupakan pangsa pasar yang sangat besar bagi industri keuangan syariah, karena Indonesia juga merupakan negara dengan penduduk muslim terbanyak di dunia. Akan tetapi, hal ini tidak serta merta menjadikan lembaga keuangan syariah di Indonesia menjadi global player keuangan syariah. Hal ini dikarenakan masih rendahnya pengetahuan dan kesadaran masyarakat terhadap ekonomi syariah. Sehingga diperlukan adanya sosialisasi dan edukasi pada masyarakat.

Pengembangan ekonomi syariah di Indonesia lebih bersifat market driven dan dorongan botton up dalam memenuhi kebutuhan masyarakat. Dengan demikian, pengembangan ekonomi syariah di Indonesia lebih bertumpu pada sektor riil, dan ini merupakan suatu kelebihan tersendiri bagi lembaga keuangan syariah di Indonesia. Hal ini yang menjadikan lembaga keuangan syariah lebih tahan menghadapi krisis ekonomi tahun 1998 dibandingkan dengan lembaga keuangan konvensional. Berbeda dengan Malaysia dimana perkembangan keuangan syariahnya lebih bertumpu pada sektor keuangan. Akan tetapi, peranan pemerintah dalam mendorong perkembangan ekonomi syariah di Malaysia lebih baik jika dibandingkan dengan di Indonesia, baik dalam dukungan 
regulasi maupun dalam penempatan dana pemerintah dan perusahaaan milik negara. Sehingga total aset lembaga keuangan syariah di Malaysia meningkat dengan signifikan. Sehingga Malaysia memiliki skala ekonomi dan efisiensi yang lebih baik dibandingkan Indonesia.

Keunggulan keuangan syariah Indonesia lainnya yaitu regulatori regime yang dinilai lebih baik. Hal ini dikarenakan di Indonesia yang memiliki kewenangan untuk mengeluarkan fatwa terpusat pada Dewan Syariah Nasional (DSN) dan Majelis Ulama Indonesia (MUI), sedangkan di negara lain dapat dikeluarkan oleh perorangan ulama sehingga peluang terjadinya perbedaan sangat besar. Sampai saat ini pemerintah telah menerbitkan tiga UU tetang perbankan Syariah yaitu UU No 7 tahun 1992, UU No 10 tahun 1998, dan UU No 21 tahun 2008. Sedangkan DSN-MUI telah mengeluarkan 119 atwa terkait ekonomi Syariah.

Kendala yang dihadapi Indonesia dalam pengembangan ekonomi syariah terutama pada kurangnya sumber daya manusia dan pakar ekonomi syariah. Maraknya lembaga keuangan syariah di Indonesia tidak diimbangi dengan sumber daya manusia yang memadai, terutama sumber daya manusia yang memiliki latar belakang disiplin keilmuan ekonomi syariah. Sebagian besar sumber daya manusia pada lembaga keuangan syariah berlatar belakang disiplin ilmu ekonomi konvensional. Keadaan ini mengakibatkan akselerasi hukum Islam dalam lembaga keuangan syariah kurang cepat dapat diakomodasikan sehingga pengembangan lembaga keuangan syariah menjadi lambat (Sudarsono, 2012).

Tantangan yang dihadapi lembaga keuangan syariah menghadapi MEA adalah inovasi pengembangan produk dan layanan yang kompetitif dan berbasis kebutuhan masyarakat. Pengembangan produk keuangan syariah tidak boleh sekedar mengimitasi produk keuangan konvensional. Lembaga keuangan syariah harus menciptakan produk dan layanan yang khas yang dapat memenuhi kebutuhan nyata masyarakat. Hal ini dikarenakan sebagian besar masyarakat muslim di Indonesia lebih mengedepankan aspek layanan dan kemudahan dibandingkan aspek syariah.

\section{Strategi Ekonomi Syariah} Menghadapi MEA

a. Peningkatan kualitas dan kuantitas sumber daya manusia

Peningkatan kualitas dan kuantitas sumber daya manusia lembaga keuangan syariah mutlak diperlukan. Hal ini diperlukan untuk memicu perkembangan 
Yayat Rahmat $\mathrm{H}$, Analisis Peluang dan Tantangan Lembaga Keuangan Syari'ah...

ekonomi syariah di Indonesia. Menjamurnya lembaga keuangan syariah tidak serta merta meningkatkan pangsa pasar lembaga keuangan syariah. Hal ini disebabkan penambahan lembaga keuangan syariah tersebut tidak diimbangi dengan peningkatan kualitas dan kuantitas sumber daya manusia yang memiliki keahlian dan latar belakang ekonomi syariah. Oleh karena itu, pembentukan lembaga pendidikan dan pelatihan ekonomi syariah mutlak diperlukan, sebagai usaha untuk mengembangkan system pendidikan yang mengintegrasikan teori dan praktik ekonomi syariah. Dengan demikian diharapkan dapat meningkatkan integritas lembaga keuangan syariah di tengah-tengah masyarakat akademik dan non akademik.

Peningkatan sumber daya ekonomi syariah diperlukan untuk mengisi gap yang ada, agar tidak diisi oleh tenaga kerja dari negara lain, mengingat salah satu kesepakatan dalam MEA adalah freedom of movement for skilled and talented labours. Hal ini merupakan tantangan yang serius, mengingat pusat-pusat pendidikan dan pelatihan keuangan dan perbankan syariah berada di luar negeri seperti Bahrain, Uni Emirat Arab, dan Malaysia.

b. Sosialisasi dan edukasi pada masyarakat
Indonesia merupakan negara dengan penduduk muslim terbanyak di dunia. Akan tetapi kenyataan ini tidak serta merta menjadikan Indonesia menjadi negara yang memiliki aset dan pangsa pasar ekonomi syariah terbesar di dunia. Hal ini dikarenakan masih rendahnya pengetahuan dan kesadaran masyarakat terhadap ekonomi syariah. Kurangnya sosialisasi dan edukasi pada masyarakat tentang keberadaan lembaga keuangan syariah menjadi penyebab utamanya. Sosialisasi tidak sekedar memperkenalkan kebaradaan lembaga keuangan syariah di suatu tempat, tetapi juga mengedukasi masyarakat tentang mekanisme produk dan instrument-instrumen keuangan yang ada pada lembaga keuangan syariah. Jika sosialisasi dan edukasi ini berjalan dengan baik, maka perkembangan lembaga keuangan syariah akan lebih cepat dan mampu bersaing dengan lembaga keuangan konvensional dan lembaga keuangan syariah dari negara ASEAN yang lain. Hal ini dikarenakan lembaga keuangan syariah Indonesia lebih memahami struktur dan keadaan pasar di Indonesia dibandingkan dengan lembaga keuangan dari negara lain.

Sosialisasi juga dapat dilakukan dengan memberikan kesempatan seluasluasnya bagi lembaga keuangan konvensional untuk membuka kantor 
cabang syariah atau pihak lain yang mampu secara legalitas dan materi untuk mendirikan lembaga keuangan syariah di seluruh wilayah Indonesia. Selain sebagai sarana mensosialisasikan lembaga keuangan syariah, langkah ini juga diperlukan untuk mengurangi dampak buruk dari riba, maysir, dan gharar bagi masyarakat (Sudarsono, 2012).

c. Peningkatan layanan dan diferensiasi produk

Sebagian besar masyarakat Indonesia menempatkan kemudahan dan kualitas layanan di atas aspek syariah. Hal ini dapat dilihat dari pangsa pasar keuangan syariah yang masih relatif kecil dibandingkan dengan pangsa pasar keuangan konvensional. Penyebab utamanya adalah dikarenakan kemudahan mengakses dan kualitas layanan lembaga keuangan konvensional masih lebih baik dibandingkan lembaga keuangan syariah. Akses jaringan kantor lembaga keuangan syariah masih terbatas sehingga sulit dijangkau oleh seluruh kalangan masyarakat.

Selain itu, diferensiasi produk keuangan syariah di Indonesia masih terbatas. Hal ini disebabkan oleh faktor bisnis model industri keuangan syariah di Indonesia, khususnya perbankan syariah, yang lebih fokus pada pemenuhan kebutuhan di sektor riil dan sangat menjaga 'maqasid syariah'. Hal ini berbeda dengan negara lain yang peranan produk-produk di sektor keuangan (pasar uang dan pasar modal) lebih dominan. Ditambah lagi pembiayaan dengan akad murabahah atau yang berbasis jual beli merupakan pembiayaan yang paling banyak dan berada di kisaran $60 \%$. Sedangkan $40 \%$ sisanya terdiri dari pembiayaan mudharabah, musyarakah, salam, istishna, ijarah, dan qardh (Hidayat, 2017).

Secara esensi, struktur pengembangan keuangan syariah di Indonesia akan lebih kuat dibanding dengan negara lain. Tetapi secara efisiensi, keuangan syariah di Indonesia akan lebih rendah karena skala ekonomi yang relatif kecil. Lembaga keuangan syariah harus mampu membuat inovasi produk dan layanan yang kompetitif dan berbasis kebutuhan masyarakat. Pengembangan produk keuangan syariah tidak boleh sekedar mengimitasi produk keuangan konvensional. Lembaga keuangan syariah harus menciptakan produk dan layanan yang khas yang dapat memenuhi kebutuhan nyata masyarakat. Hal ini dikarenakan sebagian besar masyarakat muslim di Indonesia lebih mengedepankan aspek layanan dan kemudahan dibandingkan aspek syariah. Dengan demikian diharapkan pangsa pasar 
Yayat Rahmat H, Analisis Peluang dan Tantangan Lembaga Keuangan Syari'ah...

lembaga keuangan syariah dapat meningkat sehingga dapat lebih efisien dalam kegiatan operasionalnya.

d. Dukungan dari semua stakeholder

Dukungan dari seluruh stakeholder keuangan syariah mutlak diperlukan, baik dari praktisi, akademisi, ulama, dan pemerintah. Para praktisi diharapkan mampu untuk me-menage lembaga keuangan syariah agar mampu bersaing dengan lembaga keuangan dari dalam dan luar negeri. Akademisi diperlukan untuk melakukan penelitian dan pengkajiang ekonomi syariah sehingga dapat memperkaya khazanah keilmuan ekonomi syariah. Selain itu, akademisi juga menjadi pelopor dalam pendidikan, pembinaan, dan pelatihan ekonomi syariah. Hal ini diperlukan untuk meningkatkan kualitas dan kuantitas sumber daya manusia pada bidang ekonomi syariah.

Pemerintah dan ulama dalam hal ini DSN dan MUI, harus mampu mendorong pemenuhan legalitas instrumen syariah untuk memberi ruang yang lebih besar guna tumbuhnya keuangan syariah. Pengembangan legalisasi ekonomi syariah dipengaruhi oleh permasalahanpermasalahan yang muncul. Kerangka hukum yang mampu menyelesaikan permasalahan ekonomi syariah secara komprehensif harus segera dibuat. Terdapat beberapa kekhususan yang tidak dapat dipersamakan dalam ekonomi syariah sehingga penggunaan kerangka hukum konvensional menjadi kurang memadai. Untuk itu, diperlukan kompilasi hukum ekonomi/keuangan syariah yang disepakati bersama untuk dijadikan rujukan dan disahkan oleh negara, mengingat masih terjadi perbedaan interpretasi hukum fiqih dikarenakan perbedaan mazhab. Upaya penyempurnaan kerangka hukum ini juga perlu dilakukan dalam skala global untuk menyelesaikan perselisihan yang mungkin terjadi dalam transaksi keuangan syariah antar negara. Penyempurnaan kerangka hukum akan memberikan suasana yang kondusif bagi pengembangan keuangan syariah, baik secara nasional maupun global (Alamsyah, 2012).

Pemerintah dapat menjadi pemain kunci dalam pengembangan ekonomi syariah di Indonesia. Dukungan regulasi dan penempatan modal pemerintah dan perusahaan milik pemerintah sangat diperlukan untuk menambah aset dan skala ekonomi keuangan syariah. Dengan demikian lembaga keuangan syariah menjadi lebih efisien dalam operasionalnya, sehingga dapat meningkatkan daya saing di kancah Masyarakat Ekonomi ASEAN (MEA).

\section{SIMPULAN}


Kelebihan yang dimiliki LKS di Indonesia sehingga berpeluang untuk bisa meningkatkan daya saing yaitu: (1) Negara mayoritas muslim terbesar di dunia, (2) memiliki sumber daya alam yang melimpah, (3) Pengembangan ekonomi syariah di Indonesia lebih bersifat market driven dan dorongan botton up sehingga lebih bertumpu pada sektor riil, dan (4) Lembaga yang berwenang mengeluarkan fatwa di Indonesia adalah Dewan Syariah Nasional (DSN) dan Majelis Ulama Indonesia (MUI) dan bersifat independen. Dengan demikian resiko terjadinya perbedaan fatwa dapat diminimalisir.

Kekurangan LKS di Indonesia untuk meningkatkan daya saing yaitu: Rendahnya kualitas dan kuantitas sumber daya manusia dengan latar belakang ekonomi Syariah, (2) Pangsa pasar keuangan syariah yang masih relatif kecil dibandingkan dengan keuangan konvensional, (3) Tingkat pemahaman dan kesadaran syariah masyarakat masih kurang dalam berekonomi, (3) Kurangnya inovasi pengembangan produk dan layanan yang kompetitif dan berbasis kebutuhan masyarakat, (4) Kurangnya dukungan dari pemerintah baik dukungan berupa regulasi maupun dukungan modal pemerintah.

Strategi yang harus dilakukan LKS di Indonesia untuk meningkatkan daya saing sehingga mampu bertahan dalam persaingan MEA yaitu: (1) Peningkatan kualitas dan kuantitas sumber daya manusia, (2) Sosialisasi dan edukasi pada masyarakat, (3) Peningkatan layanan dan diferensiasi produk, dan (4) Dukungan dari semua stakeholder terutama pemerintah.

\section{RUJUKAN}

Ahmed, Abdulrahman Yousri. (2002). Theoritical Foundation of Islamic Economics. .Jeddah: Islamic Research and Training Institute Islamic Development Bank.

Alamsyah, Halim. (2012). Perkembangan dan Prospek Perbankan Syariah Indonesia: Tantangan dalam Menyongsong MEA 2015, Disampaikan dalam Ceramah Ilmiah Ikatan Ahli Ekonomi Islam (IAEI), Milad ke-8 IAEI, 13 April 2012.

BPS (2010), Penduduk Menurut Kelompok Umur dan Agama yang Dianut. Tersedia di: http://sp2010.bps.go.id/index.php/sit e/tabel?tid=320\&wid=0. $\quad$ Diakses pada 10 Mei 2018.

Chapra, M Umer. (2002). What is Islamic Economics? Jeddah: Islamic Research and Training Institute Islamic Development Bank. 
Yayat Rahmat $\mathrm{H}$, Analisis Peluang dan Tantangan Lembaga Keuangan Syari'ah...

Hidayat, Yayat Rahmat. (2017). Analisis Pencapaian Tujuan Bank Syariah Sesuai UU No 21 Tahun 2008. Jurnal Amwaluna Vol. 1 No. 1 Januari 2017 hal. 34-50.

Hosen, M Nadratuzzaman dan Ali, AM Hasan. (2007). Tanya Jawab Ekonomi Syariah. Jakarta: PKES Publishing.

Karim, Adiwarman A. (2013). Ekonomi Mikro Islam, Edisi Ketiga. Jakarta: PT. Rajagrafindo Persada.

Kurnia, Nenny dkk. (2015). Islamic Finance Outlook 2015. Karim Consulting Indonesia.

Nawawi, Ismail. 2009. Ekonomi Islam: Perspektif Teori, Sistem, dan Aspek Hukum. Surabaya: CV. Putra Media Nusantara.

OJK. (2018), Statistik Perbankan Indonesia Bulan Maret 2018. Jakarta: Otoritas Jasa Keuangan.

OJK. (2017), Statistik Perbankan Syariah Bulan Desember 2017. Jakarta: Otoritas Jasa Keuangan.

Shidqi, M. Nejatullah. (2004). Riba, Bank Interest and the Rational of its Prohibition. Jeddah: Islamic Research and Training Institute Islamic Development Bank.
Sudarsono, Heri. (2012). Bank dan Lembaga Keuangan Syariah: Deskripsi dan Ilustrasi. Yogyakarta: Ekonisia.

Suhendi, Hendi. (2011). Fiqh Muamalah. Jakarta: PT. Rajagrafindo Persada.

UU No.2 Tahun 1992.Tentang Usaha Perasuransian.

Wangke, Humprey, Peluang Indonesia dalam MEA 2015, Info Singkat Hubungan Internasional, Vol. VI, (Mei 2014). 